\title{
Molecular characterization of Toxoplasma gondii and Sarcocystis spp. in raw kibbeh and other meat samples commercialized in Botucatu, Southeastern Brazil
}

\author{
Caracterização molecular de Toxoplasma gondii e Sarcocystis spp. em amostras \\ de quibe cru e de outras carnes comercializadas em Botucatu, \\ Região Sudeste do Brasil \\ Helio Langoni* (D); Diego Generoso'; Ênio Yoshinori Hayasaka; Karine Bott Mantovan; \\ Benedito Donizete Menozzi'; Virgínia Bodelão Richini-Pereira²; Rodrigo Costa da Silva³ \\ ${ }^{1}$ Serviço de Diagnóstico de Zoonoses, Departamento de Produção Animal e Medicina Veterinária Preventiva, Faculdade de Medicina \\ Veterinária e Zootecnia, Universidade Estadual Paulista - UNESP, Botucatu, São Paulo, SP, Brasil \\ ${ }^{2}$ Laboratório Regional de Bauru, Instituto Adolfo Lutz, Bauru, SP, Brasil \\ ${ }^{3}$ Universidade do Oeste Paulista - UNOESTE, Presidente Prudente, SP, Brasil
}

\begin{abstract}
How to cite: Langoni H, Generoso D, Hayasaka EY, Mantovan KB, Menozzi BD, Richini-Pereira VB, et al. Molecular characterization of Toxoplasma gondii and Sarcocystis spp. in raw kibbeh and other meat samples commercialized in Botucatu, Southeastern Brazil. Braz J Vet Parasito/ 2021; 30(2): e029320. https://doi.org/10.1590/S1984-29612021051
\end{abstract}

\begin{abstract}
Toxoplasmosis occurs worldwide causing economic losses to the animal production and problems to the public health. The study aimed to detect Toxoplasma gondii and Sarcocystis spp.in 141 meat products from commercial meat cuts of pork, beef, and kibbeh sold in commercial markets from Botucatu, SP, Brazil. Samples were bioassayed in mice to isolate the parasite, and the parasite DNA detected by PCR targeting the 529 base pairs repeat element region (PCR-529-bp). All samples resulted negative on bioassay, whereas PCR positive for 9 (6,38\%), distributed as 5/48 beef, 3/49 pork, and 1/44 kibbeh. PCR-positive were investigated for the the parasite genotype using multiplex-, nested-, and RFLP-PCR for 11 markers (SAG1, 5'-3'SAG2, alt.SAG2, SAG3, B-TUB, GRA6, L358, c22-8, C29-6, PK1, Apico). Complete genotype was determined on just one PCR-positive sam

le that matched MAS, TgCkBr89 and TgCkBr147 isolates already identified. In addition, nested- and RFLP-PCR targeting $18 \mathrm{~S}$ rRNA was run for all PCR-positive samples and, the products, sequenced and aligned to the GenBank at NCBI website. Four samples showed 100\% homology with T. gondii (GenBank \#L37415.1), three with Sarcocystis hominis (GenBank \#AF006471.1), two Sarcocystis cruzi (GenBank \#AF176934.1), and one Sarcocystis hirsuta (GenBank \#AF006469.1), indicating the circulation of T. gondii and Sarcocystis spp.
\end{abstract}

Keywords: Toxoplasmosis, sarcocystosis, meat products, food safety, public health, molecular techniques.

\section{Resumo}

A toxoplasmose está mundialmente distribuída e causa perdas na produção animal e problemas de saúde pública. Objetivou-se detectar Toxoplasma gondii e Sarcocystis spp. em 141 produtos cárneos de origem suína (49), bovina (48) e de quibe cru (44), comercializados em mercados de Botucatu, SP, Brazil. Realizou-se bioensaio das amostras em camundongos para isolamento do parasita, e detecção do DNA pela reação em cadeia pela polimerase, tendo como alvo a região do elemento repetitivo de 529 pares de bases (PCR-529-bp). Todas as amostras foram negativas ao bioensaio e $9(6,38 \%)$ positivas à $P C R$, sendo $5 / 48$ bovinas, $3 / 49$ suínas e 1/44 quibe. Determinou-se a genotipagem das amostras positivas pela multiplex-, nested- e RFLP-PCR com 11 marcadores (SAG1, 5'-3'SAG2, alt.SAG2, SAG3, B-TUB, GRA6, L358, c22-8, c29-6, PK1, Apico). Obteve-se genótipo completo em uma amostra,

Received December 18, 2020. Accepted April 26, 2021.

Financial support: Conselho Nacional de Desenvolvimento Científico e Tecnológico (CNPq) (Process n. 559471/2010-6 and CAPES-DS)

*Corresponding author: Helio Langoni. E-mail: helio.langoni@unesp.br 
semelhante a outros já identificados (MAS, TgCkBr89 e TgCkBr147). Nested- e RFLP-PCR do gene 18S rRNA das amostras positivas à PCR foram realizadas, e os produtos da nested-PCR, sequenciados e alinhados com dados do GenBank no NCBI. Quatro apresentaram 100\% de homologia com T. gondii (L37415.1), duas Sarcocystis hominis (AF006471.1), duas Sarcocystis cruzi (AF176934.1), uma Sarcocystis hirsuta (AF006469.1), indicando a circulação de T. gondii e Sarcocystis spp.

Palavras-chave: Toxoplasmose, sarcocistose, produtos cárneos, segurança alimentar, saúde pública, técnicas moleculares.

\section{Introduction}

Toxoplasma gondii is an obligate intracellular protozoan parasite, which causes toxoplasmosis, a worldwide distributed zoonosis, infecting homoeothermic hosts, including humans (Acha \& Szyfres, 2003). Felids are the definitive hosts, while livestock animals develop tissue cysts (bradyzoites) in different tissues, e.g. the musculature (intermediate hosts). Contaminated food increases the importance of this infection to the public health. This anthropozoonosis can cause severe disease on newborns and immunosuppressed patients (Millar et al., 2007). Many different risk factors can be associated to this infection, including the ingestion of food containing the cysts as well as its handling by butchers and people who manipulate it.

Sarcocystis spp. are obligate protozoan parasites causing sarcocystosis, another worldwide distributed zoonosis. More than hundred species of Sarcocystis infect mammals, but only two are known to parasitize the human intestine, ie. S. suihominis and S. hominis. Other species, ie. S. hirsuta, S. miescheriana, S. gigantea, S. cruzi, and others, affect animals (Acha \& Szyfres, 2003). All Sarcocystis spp. have obligatory heteroxenous life cycle. Carnivores and omnivores are usually definitive (sporogony - sexual stage) hosts while omnivores and herbivores are intermediate hosts (merogony - asexual stage). The definitive host acquires them upon ingesting meat from intermediate hosts infected with mature cysts (sarcocysts), containing the parasite (infective bradyzoites). The intermediate host acquires the infection upon consuming oocysts or mature sporocysts shed by the definitive hosts in their feces (Lindsay et al., 1995; Dehkordi et al., 2017).

It is extremely important to search for T. gondii (Acha \& Szyfres, 2003) and Sarcocystis spp. (Dehkordi et al., 2017) in meat products used for human consumption since they constitute a transmission route responsible for foodborne outbreaks (Acha \& Szyfres, 2003). The infection in livestock animals can be detected by serological tests and bioassay in mice (Kijlstra \& Jongert, 2009).

Serology may be used to have a screening of the T. gondii infection (Acha \& Szyfres, 2003). de Macedo et al. (2012) observed $48.3 \%$ dairy cows and 3.7\% fetuses seropositive for $T$. gondii using the indirect fluorescent antibody technique (IFAT), while bioassay in mice resulted positive in only $10 \%$ dairy cows and $23.3 \%$ fetuses. Spagnol et al. (2009) reported $11.83 \%$ seropositive cattle among 600 slaughtered animals compared to $41.4 \%$ observed by Daguer et al. (2004) among 348 slaughtered animals. Furthermore, Da Rosa et al. (2011) observed $30.4 \%$ seropositive pigs among 353 sampled, while Da Silva et al., (2011) detected 10.96\% seropositive slaughtered sheep among 602 sampled.

Since meat products participate to the transmission chain of toxoplasmosis to animals and humans, the present study aimed to detect T. gondii and Sarcocystis spp. in meat products sold at commercial markets in Botucatu, SP, Brazil.

\section{Materials and Methods}

\section{Sampling}

Meat samples were sampled from different markets from Botucatu, a city placed at the Mid-West region of Sao Paulo State, at the Southeastern Region from Brazil (22 $52^{\prime} 20^{\prime \prime}$; $\left.48^{\circ} 26^{\prime} 37^{\prime \prime} \mathrm{W}\right)$. Samples of pork, beef cuts, and raw kibbeh were obtained from four butcher shops (A, B, C and D) and one supermarket, monthly, along 10 months to increase the diversity of the origin of the commercialized meat products sold by the suppliers. One hundred forty-one meat cuts were sampled, as follows: swine gammon (49), bovine shank (48), and raw kibbeh (44). Samples were individually packed in sterile plastic bags, identified, and stored in an isothermal box, at $4^{\circ} \mathrm{C}$, and processed within 1 hour. The present study was approved by the Ethics Committee on Animals Use (CEUA) of the School of Veterinary Medicine and Animal Science, UNESP, Botucatu, SP (\#155/2010). 


\section{Bioassay in mice}

All meat samples were bioassayed in 30 day-old, female albino Swiss mice (Mus musculus). The samples were weighed ( $50 \mathrm{~g}$ ) and eight fragments from different sites of each meat sample were pooled and mixed. Each pool (10 g) was individually ground, diluted $1: 5$ (w/v) in $0.18 \%$ saline solution and digested by the acid action of pepsin (Dubey, 1998). Aliquot of each pool ( $1 \mathrm{~mL}$ ) was stored at $-80^{\circ} \mathrm{C}$ for molecular assay. Five mice per pool were bioassayed with $1 \mathrm{~mL}$ suspension (per mice), using subcutaneous inoculation. Bioassayed mice were observed along 60 days. After the observational period, blood samples were drawn from all alive mice by the retro-orbital sinus puncture into a microtube without anticoagulant. The blood samples were centrifuged at $1600 \times g$ for 10 minutes, and the sera sample searched for $T$. gondii IgG antibodies using a serological test with a cut-off 1:16. All died mice, or mice inoculated with meat cut positive for T. gondii DNA detection, had the brain removed and also searched of $T$. gondii DNA using molecular technique. Samples were considered positive after detected $T$. gondii DNA or $T$. gondii IgG antibodies.

\section{Modified agglutination test (MAT)}

T. gondii IgG antibodies were searched in the blood serum samples of bioassayed mice using modified agglutination test (MAT) (Desmonts \& Remington, 1980), on 96-well U-shaped-bottom microplates (Cralplast, Brazil). The cut-off titer was 16 . Positive result was considered after the formation of a pellicle covering at least half of the well, and negative when a sediment ("button" or a "ring") was formed at the bottom of the well.

\section{Detection of T. gondii using PCR of the 529 bp fragment (PCR-529-bp)}

DNA extraction and purification of the meat samples were done using the extraction kit Illustra Tissue and cells genomic Prep Mini spin kit (GE Healthcare, USA), according to the manufacturer instructions. The concentration and the quality of the extracted DNA were determined using a Nanovue spectrophotometer (GE Healthcare, USA).

PCR-529-bp was assayed using TOX4 and TOX5 primers, targeting 529-base pairs (bp) repeat element region, which is a 200- to 300-fold repetitive in the parasite genome, and result on an amplification product of 529-bp (Homan et al., 2000). All amplified products were visualized on electrophoresis using 1.5 agarose gel. The products were visualized using the digital documentation system, Gel-Doc-it System (UVP, USA), and VisionWorks Software (UVP, USA).

\section{Genotyping}

Genotyping was assayed using 11 genetic markers (SAG1, 5'-3'SAG2, alt-SAG2, SAG3, B-TUB, GRA6, c22-8, c29-2, L358, PK1 and Apico) as Su et al. (2006), Ferreira et al. (2006) and Pena et al. (2008). The marker CS3 was included in the present study to evaluate the virulence (Khan et al., 2005). Reference strains (GT1, PTG, ME49, CTG, M7741, $\mathrm{TgCgCa1}$, MAS, and TgCatBr5) were used as controls. During genotyping, sequences of the target DNA were initially amplified by multiplex-PCR employing external primers for all biomarkers, followed by nested-PCR for individual biomarker (Su et al., 2006; Ferreira et al., 2006; Pena et al., 2008). In addition, possible co-infection with other Apicomplexa parasitic protozoa was determined using multiplex-, nested-, and RFLP-PCR of the 185 ribosomal RNA (18S rRNA) gene, according to Da Silva et al. (2009). The expected amplification product for Sarcocystis neurona (S. neurona), Neospora caninum (N. caninum), Hammondia hammondi (H. hammondi), and T. gondii was 290-bp, whereas for other Sarcocystis spp. was 310-bp. Positive controls for Sarcocystis tenella (S. tenella), S. neurona, T. gondii, H. hammondi, and N. caninum were employed.

All amplified and digested products were stained with ethidium bromide and electrophoresis using $2.5 \%$ or $3 \%$ agarose gel (depending on the marker used) was performed. The products were visualized using the digital documentation system, System Gel-doc-it.

\section{Sequencing}

The products of PCR for primers TOX4 and TOX5, and that of nested-PCR for gene 18S rRNA were purified using the purification kit Centrifugal Filter Units, MRCFOR030 (Millipore, USA) or ExoStar1-Step, US77705 (GE Healthcare, USA). DNA was quantified using the spectrophotometer Nanovue (GE Healthcare, USA), and electrophoresed on agarose gel.

Sequencing was run on an automated sequencer, Applied Biosystems 3100 (Applied Biosystems, USA), employing ABI BigDye kit and GE DYEnamic ET terminator kit (GE Healthcare, USA), and analyzed by the software Sequence 
Analyzer, using Base Caller Cimarron 3.12. The obtained sense and antisense sequences were aligned and visualized using the software BioEdit Sequence Alignment Editor 7.0.9.0. Nucleotide sequences were analyzed using Nucleotide Basic Local Alignment Search Tool (BLASTn) and compared to those deposited on GenBank nucleotide database.

\section{Statistical analyses}

All data were tabulated on Excel spreadsheet. Fisher's exact test was used to analyze the association of the PCR results, the type of meat sample (beef, pork and kibbeh), and the origin of samples (butcher shops or supermarket). A significance level of $5 \%$ was adopted (Triola, 2005).

\section{Results}

PCR-529-bp resulted positive for 9/141 (6.38\%; 95\% Cl 3.43-11.69\%) meat samples, comprehending 5/9 (55.56\%; 95\% Cl 26.24-81.29\%) beef samples, 3/9 (33.33\%; 95\% Cl 12.16-65.25\%) pork samples, and 1/9 (11.11\%; $95 \% \mathrm{Cl}$ 2.52-44.50\%) kibbeh sample ( $\mathrm{p}$-value > 0.05). Concerning to the markets, $7 / 9(77.78 \% ; 95 \% \mathrm{Cl} 44.39-93.33 \%)$ PCRpositive samples were sold by butcher shops and $2 / 9$ (22.22\%; $95 \% \mathrm{Cl}$ 6.67-55.61\%) from a supermarket (Table 1). All mice survived to the bioassay and resulted negative to the serology, including those bioassayed with PCR-positive meat samples.

A total of 3/7 (42.86\%; 95\% Cl 15.70-75.51\%) PCR-positive samples was commercialized by butcher shop A (two beef and one pork samples), while 3/7 (42.86\%; 95\% Cl 15.70-75.51\%) samples from butcher shop C (one beef, one pork, and one kibbeh samples), and 1/7 (14.29\%; 95\% Cl 3.19-52.65\%) from butcher shop B (one beef sample). No positive result for PCR was observed on meat samples from butcher shop D. Positive samples from the supermarket were from beef (one) and pork (one) (Table 2). No statistical difference was observed between the meat origin and the PCR-529-bp results ( $p$-value $>0.05$ ).

The genotyping of the nine PCR-positive samples resulted in just one (11.11\%; 95\% Cl 2.52-44.50\%) complete genotypic pattern, which matched to T. gondii (Table 3), specifically to MAS, TgCkBr89, and TgCkBr147 strains. In addition, 4/9 (44.44\%; 95\% Cl 18.71-73.76\%) samples (\#51, \#107, \#116 and \#119) resulted positive for nested-PCR (18S rRNA), amplifying 290-bp amplicons, which is suggestive of $T$. gondii. On the other hand, 5/9 other and different samples (55.56\%; 95\% Cl 26.24\%-81.29\%) resulted a single 310-bp amplicon to the same 18S rRNA target, a nonexpected pattern. Just two of that (\#115 and \#118) presented RFLP-PCR pattern that suggested S. hominis. The remaining $3 / 5$ samples (\#100, \#106, and \#112) had no pattern to RFLP-PCR.

Sequencing of the nested-PCR amplicons for $18 \mathrm{~S}$ rRNA gene matched T. gondii (GenBank accession number L37415.1) genome on four samples (44.44\%; 95\% Cl 18.71-73.76\%), confirming the expected above for those samples presenting 290-bp amplicons. Concerning the samples with 310-bp amplicons, $2 / 5$ (22.22\%; 95\% Cl 6.67-55.61) matched Sarcocystis cruzi (S. cruzi) (GenBank accession number AF176934.1), one (11.11\%; 95\% Cl 2.52-44.50\%) matched Sarcocystis hirsuta (S. hirsuta) (GenBank accession number AF006469.1), and two (22.22\%; 95\% Cl 6.6755.61) matched S. hominis (GenBank accession number AF006471.1) (Table 2).

Table 1. Percentage T. gondii DNA detection using PCR-529-bp in beef, pork and kibbeh commercialized in markets from Botucatu, SP, Brazil.

\begin{tabular}{ccccc}
\hline \multirow{2}{*}{ Markets } & $\mathbf{N}(\%)$ & \multicolumn{2}{c}{ PCR-529-bp results } \\
\cline { 3 - 5 } & & $\mathbf{n}$ & \% of positive/market (95\% CI) & \% of positive/total (95\% Cl) \\
\hline Butcher shop A & $29(20.57)$ & 3 & $10.35(3.76-26.53)$ & $33.33(12.16-65.25)$ \\
Butcher shop B & $30(21.28)$ & 1 & $3.33(0.79-16.70)$ & $11.11(2.52-44.50)$ \\
Butcher shop C & $30(21.28)$ & 3 & $10.00(3.63-25.75)$ & $33.33(12.16-65.25)$ \\
Butcher shop D & $24(17.02)$ & 0 & $0.00(0.00-0.00)$ & $0.00(0.00-0.00)$ \\
Supermarket & $28(19.85)$ & 2 & $7.14(2.19-22.77)$ & $22.22(6.67-55.61)$ \\
Total & $141(100.00)$ & 9 & $6.38(3.43-11.69)$ & $100(-)$ \\
\hline
\end{tabular}

Legend: N: number of samples per each market; n: number PCR-positive samples; \%: percentage; 95\% Cl: 95\% confidence interval. 
Table 2. DNA research for different parasites from meat products using different molecular techniques targeting 529-bp repeat element region and $18 \mathrm{~S}$ ribosomal RNA (18S rRNA).

\begin{tabular}{|c|c|c|c|c|c|c|c|c|}
\hline \multirow{3}{*}{$\#$} & \multirow{3}{*}{ Sample } & \multirow{3}{*}{ Market } & \multirow{3}{*}{$\begin{array}{c}\text { 529-bp repeat } \\
\text { element region } \\
\text { PCR }\end{array}$} & \multicolumn{5}{|c|}{ 18S rRNA gene } \\
\hline & & & & \multirow{2}{*}{ nested-PCR ${ }^{\dagger}$} & \multirow{2}{*}{ RFLP-PCR } & \multicolumn{3}{|c|}{ Sequencing } \\
\hline & & & & & & GenBank & Identity & Agent \\
\hline 51 & kibbeh & Butcher shop C & positive & 290bp & $\begin{array}{l}\text { Toxoplasma } \\
\text { gondii }\end{array}$ & L37415.1 & $100 \%$ & $\begin{array}{l}\text { Toxoplasma } \\
\text { gondii }\end{array}$ \\
\hline 100 & beef & Butcher shop A & positive & 310bp & ND & AF176934.1 & $100 \%$ & Sarcoystis cruzi \\
\hline 106 & beef & Supermarket & positive & 310bp & ND & AF006469.1 & $100 \%$ & $\begin{array}{l}\text { Sarcocystis } \\
\text { hirsuta }\end{array}$ \\
\hline 107 & pork & Supermarket & positive & $\sim 290 \mathrm{bp}$ & $\begin{array}{l}\text { Toxoplasma } \\
\text { gondii }\end{array}$ & L37415.1 & $100 \%$ & $\begin{array}{l}\text { Toxoplasma } \\
\text { gondii }\end{array}$ \\
\hline 112 & beef & Butcher shop B & positive & -310bp & ND & AF176934.1 & $100 \%$ & Sarcoystis cruzi \\
\hline 115 & beef & Butcher shop C & positive & -310bp & $\begin{array}{l}\text { Sarcocystis } \\
\text { hominis }\end{array}$ & AF006471.1 & $100 \%$ & $\begin{array}{l}\text { Sarcocystis } \\
\text { hominis }\end{array}$ \\
\hline 116 & pork & Butcher shop C & positive & $\sim 290 \mathrm{bp}$ & $\begin{array}{l}\text { Toxoplasma } \\
\text { gondii }\end{array}$ & L37415.1 & $100 \%$ & $\begin{array}{l}\text { Toxoplasma } \\
\text { gondii }\end{array}$ \\
\hline 118 & beef & Butcher shop A & positive & 310bp & $\begin{array}{l}\text { Sarcocystis } \\
\text { hominis }\end{array}$ & AF006471.1 & $99 \%$ & $\begin{array}{l}\text { Sarcocystis } \\
\text { hominis }\end{array}$ \\
\hline 119 & pork & Butcher shop A & positive & $\sim 290 \mathrm{bp}$ & $\begin{array}{l}\text { Toxoplasma } \\
\text { gondii }\end{array}$ & L37415.1 & $100 \%$ & $\begin{array}{l}\text { Toxoplasma } \\
\text { gondii }\end{array}$ \\
\hline
\end{tabular}

bp: base pairs; ND: result not determined; \#: ID sample; ${ }^{t}$ : base pair size. BLAST results: L37415.1: T. gondii 18S ribosomal RNA gene, complete sequence; AF176934.1: S. cruzi strain 12hcr60 18S ribosomal RNA gene, partial sequence; AF006469.1: S. hirsuta 18S ribosomal RNA gene, complete sequence; AF006471.1: S. hominis 18S ribosomal RNA gene, complete sequence.

Table 3. Genotypic characterization of Toxoplasma gondii from a PCR positive sample of kibbeh commercialized in Botucatu, SP, Brazil.

\begin{tabular}{|c|c|c|c|c|c|c|c|c|c|c|c|c|c|c|c|c|}
\hline \multirow{2}{*}{$\#$} & \multirow{2}{*}{ Sample } & \multirow{2}{*}{$\begin{array}{l}\text { Survival } \\
\text { (days)* }\end{array}$} & \multicolumn{12}{|c|}{ Genetic Markers } & \multirow{2}{*}{ Genotype } & \multirow{2}{*}{$\begin{array}{c}\text { Typing } \\
\text { reference }\end{array}$} \\
\hline & & & SAG1 & 5'-3'SAG2 & $\begin{array}{l}\text { alt- } \\
\text { SAG2 }\end{array}$ & SAG3 & B-TUB & GRA6 & c22-8 & c29-2 & L358 & PK1 & Apico & CS3 & & \\
\hline \multirow[t]{3}{*}{51} & Kibbeh & 60 & nd & I & II & III & III & III & $\mathrm{u}-1$ & 1 & 1 & III & 1 & nd & MAS & $\begin{array}{l}\text { Su et al. } \\
\text { (2006) }\end{array}$ \\
\hline & & & & & & & & & & & & & & & $\operatorname{TgCkBr89}$ & $\begin{array}{l}\text { Dubey et al. } \\
\quad(2008)\end{array}$ \\
\hline & & & & & & & & & & & & & & & $\operatorname{TgCkBr} 147$ & $\begin{array}{l}\text { Dubey et al. } \\
\text { (2008) }\end{array}$ \\
\hline
\end{tabular}

\#: ID sample; nd: no data; u-1: unique-1. *Period of observation of mice $=60$ days p.i.

\section{Discussion}

The search for zoonotic agents in meat for human consumption has high importance, considering its risk to public health (Acha \& Szyfres, 2003). In natura meat products, and those derived from beef and pork, are important protein sources for humans. Livestock animals play an important role to the spread of $T$. gondii infection, since they harbor tissue cysts containing bradyzoites and constitute one of the possible transmission routes to humans. The ingestion of viable tissue cysts by a non-immune host may result in an infection with the parasite (Tenter, 2009).

Tissue cyst formation varies among animals and is related to the parasite organotropism (Dubey \& Jones, 2008). The cysts present in carcasses and meat products remain viable and infective for a variable time. However, bioassay in mice requires a minimum infective dose, the virulence, and the absence of agents that inactivate the parasite to isolate the parasite (Mendonça et al., 2004). 
The PCR-positive and bioassay-negative results in the present study indicate presence of the parasite DNA on the inoculated material, but its viability was compromised. The same was observed by Mendonça et al. (2004). These authors detected $T$. gondii DNA in 70 sausage samples sold in commercial markets, but all samples resulted negative to the bioassay in mice. Thus, the study on commercialized meat products must take into consideration the conservation period and status of the investigated meat. Although it is known that freezing inactivates bradyzoites. According to Bayarri et al. (2012), freezing is enough to inactivate $T$. gondii tachyzoites and bradyzoites.

The search for $T$. gondii in meat is important to evaluate the transmission chain of this protozoan, especially on raw kibbeh. Raw kibbeh is usually consumed in natura. This increases the risk to the consumers, once this type of meat is prepared from different species, i.e., sheep (Silva et al., 2003). Benitez et al. (2017) reported higher seroprevalence for T. gondii antibodies in dog owners (41.54\%) from Londrina, PR, Brazil, than their dogs $(16.32 \%)(p<0.01)$. Concerning some analyzed variables, $97.7 \%$ owners reported meat consumption and occasional undercooked meat in common dishes, ie barbecue $(32.8 \%)$, fried meat $(24.5 \%)$, and raw kibbeh $(17,8 \%)$, while just $30.2 \%$ offered sporadically meat to the dogs. This important data reflects the importance of the food care after buying meat cuts or products even on butcher shops or supermarkets. The identification of $T$. gondii and Sarcocystis spp. in beef and sheep, as kibbeh, products does alert the population to adopt control measures and meat treatments before consuming or offering to the pets.

The consumption of kibbeh may be important to the occurrence of several food-borne outbreaks involving meat products, including toxoplasmosis (Bonametti et al., 1997; Cook et al., 2000; Kijlstra \& Jongert, 2008). On a public health concern, Hashimoto Pugliesi et al. (2020) observed 16.9\% pregnant women from Maringa, PR, eat raw or undercooked meat, $11.8 \%$ eat raw kibbeh, and $27.2 \%$ eat rare barbecue. Even with low rates, the $T$, gondii susceptibility is there. Bonametti et al. (1997) reported an outbreak with 17 human Toxoplasma cases after ingestion of raw kibbeh on a party in Bandeirantes, PR, Brazil. All patients presented T. gondii IgM and IgG antibodies.

T. gondii infection, with no co-infection, was detected in pork and kibbeh samples. Pigs and sheep are some of the most important animals related to the toxoplasmosis transmission chain, involving meat products (Tenter et al., 2000). In contrast to Brazil, livestock animal from Colombia are high exposed to the parasite. Franco-Hernandez et al. (2016) detected T. gondii DNA on 79/120 (43\%) meat samples for human consumption in Colombia, being 33 from chicken, 22 from beef, and 24 from pork.

Concerning the meat products from cattle, T. gondii (PCR-529-bp) and Sarcocystis spp. (sequencing, 18S rRNA) were also detected in this study. Three distinct Sarcocystis species were identified, including S. cruzi, S. hirsuta and S. hominis. These results show the relevance of bovine meat to the public health, since T. gondii and $S$. hominis have a zoonotic impact. Cattle are intermediate hosts of Sarcocystis sp. (Carlton \& McGavin, 2005), being affected all three identified species, e.g., S. cruzi, S. hominis and S. hirsuta (Lindsay et al., 1995). The macroscopic observation of the parasite on bovine musculature is crucial to diagnose the parasitosis during meat inspection at the slaughterhouse (Fortes, 2004).

Genotyping by employing 11 genotypic markers has been adopted worldwide for T. gondii DNA detection and analysis. Reports from South America have indicated significant genotypic variability identified by this technique, which allowed the characterization and phylogeny of different $T$. gondii isolates (Da Silva et al., 2009). Several studies have confirmed the high genetic diversity of the parasite in South America since it has been isolated from several animal species, such as goats from Ceará, Brazil (Cavalcante et al., 2007), dogs and cats from Colombia (Dubey et al., 2006a, Dubey et al., 2007a), and chicken from Nicarágua (Dubey et al., 2006b) and from Brazil (Dubey et al., 2007b). In Mid-West region of Sao Paulo State, Brazil, T. gondii isolates from sausages have already been characterized using molecular techniques (Vieira Da Silva et al., 2005).

According to the genotyping, T. gondii isolate was characterized as atypical and matched to MAS, $\mathrm{TgCkBr} 89$ and $\mathrm{TgCkBr} 147$, already identified isolates. MAS was isolated from a human patient in France, and it was classified as virulent (Grigg et al., 2001). In addition, TgCkBr89 was isolated from chickens from Rio de Janeiro State, Brazil (Dubey et al., 2003), whereas TgCkBr147 was isolated from chickens from Rio Grande do Sul, Brazil (Dubey et al., 2007b), both isolates virulent to mice and genotyped by Dubey et al. (2008). The other PCR-positive samples did not present RFLP-PCR patterns to determine the $T$. gondii genotype. This information suggests a low quantity of T. gondii DNA. Studies researching new genotypes in production animals must be encouraged in order to understand the dynamics of the distribution of classic and atypical $T$. gondii genotypes, contributing to the active vigilance and epidemiology of toxoplasmosis, especially using molecular epidemiology.

For the prophylaxis of toxoplasmosis, other measures are evidently related to the epidemiological transmission chain of this zoonosis, i.e., the care of definitive hosts like primoinfected felids (domestic cat). Domestic cat is 
an important link to toxoplasmosis transmission chain since it shed oocysts on their feces, contributing to the environmental contamination, the spread and the maintenance of the infection among humans and animals. In addition, the education of cat owners, specially, limiting the hunting opportunities and avoiding feeding them with raw meat are easy to implement measures and may reduce acquiring new infections (Opsteegh et al., 2015).

\section{Conclusions}

The present study revealed the presence of $T$. gondii and Sarcocystis spp. in meat products commercialized in Botucatu, as well as the possible co-infection T. gondii and Sarcocystis sp. (S. hominis, S. cruzi or S. hirsuta) in beef. Special attention to $S$. hominis should be applied due to its zoonotic impact, as well as to the occurrence of $T$. gondii in beef and pork meat products.

\section{Acknowledgements}

We thank Conselho Nacional de Desenvolvimento Científico e Tecnológico [National Council for Scientific and Technological Development (CNPq)] for the financial support (Process n. 559471/2010-6 and CAPES-DS) through the Master's scholarship.

\section{References}

Acha P, Szyfres B. Zoonosis y enfermedades transmisibles communes al hombre y a los animals. 3rd ed. Washington: Organización Panamericana de la Salud; 2003.

Bayarri S, Gracia MJ, Lázaro R, Pérez-Arquillué C, Herrera A. Toxoplasma gondii in meat and food safety implications - a review. In: Lorenzo-Morales J. Zoonosis. Croatia: InTech; 2012. p. 229-255. http://dx.doi.org/10.5772/38833

Benitez AN, Martins FDC, Mareze M, Santos NJR, Ferreira FP, Martins CM, et al. Spatial and simultaneous representative seroprevalence of anti-Toxoplasma gondii antibodies in owners and their domiciled dogs in a major city of southern Brazil. PLoS One 2017; 12(7): e0180906. http://dx.doi.org/10.1371/journal.pone.0180906. PMid:28732033.

Bonametti AM, Passos JN, da Silva EM, Bortoliero AL. Surto de toxoplasmose aguda transmitida através da ingestão de carne crua de gado ovino. Rev Soc Bras Med Trop 1997; 30(1): 21-25. http://dx.doi.org/10.1590/S0037-86821997000100005. PMid:9026828.

Carlton WW, McGavin MD. Patologia veterinária especial. 2nd ed. Porto Alegre: Artmed; 2005.

Cavalcante ACR, Ferreira AM, Melo MN, Fux B, Brandão GP, Vitor RWA. Virulence and molecular characterization of Toxoplasma gondii isolated from goats in Ceará, Brazil. Small Rumin Res 2007; 69(1-3): 79-82. http://dx.doi.org/10.1016/j.smallrumres.2005.12.023.

Cook AJ, Gilbert RE, Buffolano W, Zufferey J, Petersen E, Jenum PA, et al. Sources of toxoplasma infection in pregnant women: European multicentre case-control study. European Research Network on Congenital Toxoplasmosis. BMJ 2000; 321(7254): 142147. http://dx.doi.org/10.1136/bmj.321.7254.142. PMid:10894691.

Da Rosa RC, Mattei RJ, Costa da Silva R, Merlini LS, Langoni H, Vieira da Silva A. Anticorpos anti-Toxoplasma gondii em suínos criados em granjas de elevado e baixo padrão sanitário no noroeste do Paraná. Rev Acad Ciênc Agrár Ambient 2011; 9(4): 435-437. http://dx.doi.org/10.7213/cienciaanimal.v9i4.12482.

Da Silva RC, Langoni H, Su C, Da Silva AV. Genotypic characterization of Toxoplasma gondii in sheep from Brazilian slaughterhouses: new atypical genotypes and the clonal type II strain identified. Vet Parasito/ 2011; 175(1-2): 173-177. http://dx.doi.org/10.1016/j. vetpar.2010.09.021. PMid:20970257.

Da Silva RC, Su C, Langoni H. First identification of Sarcocystis tenella (Railliet, 1886) Moulé, 1886 (Protozoa: Apicomplexa) by PCR in naturally infected sheep from Brazil. Vet Parasitol 2009; 165(3-4): 332-336. http://dx.doi.org/10.1016/j.vetpar.2009.07.016. PMid:19647370.

Daguer H, Vicente RT, Costa T, Virmond MP, Hamann W, Amendoeira MRR. Soroprevalência de anticorpos anti-Toxoplasma gondii em bovinos e funcionários de matadouros da microrregião de Pato Branco, Paraná, Brasil. Cienc Rural 2004; 34(4): $1133-1137$. http://dx.doi.org/10.1590/S0103-84782004000400026.

de Macedo MF, de Macedo CA, Ewald MP, Martins GF, Zulpo DL, da Cunha IA, et al. Isolation and genotyping of Toxoplasma gondii from pregnant dairy cows (Bos taurus) slaughtered. Rev Bras Parasitol Vet 2012; 21(1): 74-77. http://dx.doi.org/10.1590/ S1984-29612012000100016. PMid:22534951. 
Dehkordi ZS, Yalameha B, Sari AA. Prevalence of Sarcocystis infection in processed meat products by using digestion and impression smear methods in Hamedan, Iran. Comp Clin Path 2017; 26(5): 1023-1026. http://dx.doi.org/10.1007/s00580-0172478-3. PMid:28845151.

Desmonts G, Remington JS. Direct agglutination test for diagnosis of Toxoplasma infection: method for increasing sensitivity and specificity. J Clin Microbiol 1980; 11(6): 562-568. http://dx.doi.org/10.1128/JCM.11.6.562-568.1980. PMid:7000807.

Dubey JP. Refinement of pepsin digestion method for isolation of Toxoplasma gondii from infected tissues. Vet Parasitol 1998; 74(1): 75-77. http://dx.doi.org/10.1016/S0304-4017(97)00135-0. PMid:9493311.

Dubey JP, Jones JL. Toxoplasma gondii infection in humans and animals in the United States. Int J Parasitol 2008; 38(11): 12571278. http://dx.doi.org/10.1016/j.ijpara.2008.03.007. PMid:18508057.

Dubey JP, Graham DH, da Silva DS, Lehmann T, Bahia-Oliveira LMG. Toxoplasma gondii isolates of free-ranging chickens from Rio de Janeiro, Brazil: mouse mortality, genotype, and oocyst shedding by cats. J Parasitol 2003; 89(4): 851-853. http://dx.doi. org/10.1645/GE-60R. PMid:14533703.

Dubey JP, Su C, Cortés JA, Sundar N, Gomez-Marin JE, Polo LJ, et al. Prevalence of Toxoplasma gondii in cats from Colombia, South America and genetic characterization of T. gondii isolates. Vet Parasito/ 2006a; 141(1-2): 42-47. http://dx.doi.org/10.1016/j. vetpar.2006.04.037. PMid:16797845.

Dubey JP, Sundar N, Pineda N, Kyvsgaard NC, Luna LA, Rimbaud E, et al. Biologic and genetic characteristics of Toxoplasma gondii isolates in free-range chickens from Nicaragua, Central America. Vet Parasito/ 2006b; 142(1-2): 47-53. http://dx.doi.org/10.1016/j. vetpar.2006.06.016. PMid:16876324.

Dubey JP, Cortés-Vecino JA, Vargas-Duarte JJ, Sundar N, Velmurugan GV, Bandini LM, et al. Prevalence of Toxoplasma gondii in dogs from Colombia, South America, and genetic characterization of T. gondii isolates. Vet Parasito/ 2007a; 145(1-2): 45-50. http:// dx.doi.org/10.1016/j.vetpar.2006.12.001. PMid:17257761.

Dubey JP, Sundar N, Gennari SM, Minervino AHH, Farias NA, Ruas JL, et al. Biologic and genetic comparison of Toxoplasma gondii isolates in free-range chickens from the northern Pará state and the southern state Rio Grande do Sul, Brazil revealed highly diverse and distinct parasite populations. Vet Parasito/ 2007b; 143(2): 182-188. http://dx.doi.org/10.1016/j.vetpar.2006.08.024. PMid:16982151 .

DubeyJP, Velmurugan GV, Chockalingam A, Pena HF, de Oliveira LN, Leifer CA, et al. Genetic diversity of Toxoplasma gondii isolates from chickens from Brazil. Vet Parasito/ 2008; 157(3-4): 299-305. http://dx.doi.org/10.1016/j.vetpar.2008.07.036. PMid:18804329.

Ferreira AM, Vitor RW, Gazzinelli RT, Melo MN. Genetic analysis of natural recombinant Brazilian Toxoplasma gondii strains by multilocus PCR-RFLP. Infect Genet Evol 2006; 6(1): 22-31. http://dx.doi.org/10.1016/j.meegid.2004.12.004. PMid:16376837.

Fortes E. Parasitologia veterinária. 4th ed. São Paulo: Cone; 2004.

Franco-Hernandez EM, Acosta A, Cortés-Vecino J, Gómez-MarínJE. Survey for Toxoplasma gondii by PCR detection in meat for human consumption in Colombia. Parasitol Res 2016; 115(2): 691-695. http://dx.doi.org/10.1007/s00436-015-4790-7. PMid:26481490.

Grigg ME, Bonnefoy S, Hehl AB, Suzuki Y, Boothroyd JC. Success and virulence in Toxoplasma as the result of sexual recombination between two distinct ancestries. Science 2001; 294(5540): 161-165. http://dx.doi.org/10.1126/science.1061888. PMid:11588262.

Hashimoto Pugliesi CH, Renan Fabene M, Martins Marques FRD, Mareze M, Salci MA, Bossolani Charlo P. Estudo epidemiológico de gestantes atendidas pelo sistema único de saúde com ênfase na toxoplasmose. Saúde Col 2020; 10(58), 3803-3816. https:// doi.org/10.36489/saudecoletiva.2020v10i58p3803-3816.

Homan WL, Vercammen M, De Braekeleer J, Verschueren H. Identification of a 200- to 300-fold repetitive 529 bp DNA fragment in Toxoplasma gondii, and its use for diagnostic and quantitative PCR. Int J Parasito/ 2000; 30(1): 69-75. http://dx.doi.org/10.1016/ S0020-7519(99)00170-8. PMid:10675747.

Khan A, Taylor S, Su C, Mackey AJ, Boyle J, Cole R, et al. Composite genome map and recombination parameters derived from three archetypal lineages of Toxoplasma gondii. Nucleic Acids Res 2005; 33(9): 2980-2992. http://dx.doi.org/10.1093/nar/gki604. PMid:15911631.

Kijlstra A, Jongert E. Control of the risk of human toxoplasmosis transmitted by meat. Int J Parasitol 2008; 38(12): 1359-1370. http://dx.doi.org/10.1016/j.ijpara.2008.06.002. PMid:18694755.

Kijlstra A, Jongert E. Toxoplasma-safe meat: close to reality? Trends Parasitol 2009; 25(1): 18-22. http://dx.doi.org/10.1016/j. pt.2008.09.008. PMid:18951847.

Lindsay DS, Blagburn BL, Braund KG. Sarcocystis spp. and Sarcocystosis. BAM 1995; 5(3): 249-254.

Mendonça AO, Domingues PF, Da Silva AV, Pezerico SB, Langoni H. Detection of Toxoplasma gondii in swine sausages. Parasitol Latinoam 2004; 59: 42-45. http://dx.doi.org/10.4067/S0717-77122004000100008.

Millar PR, Daguer H, Vicente RT, Costa T, Carli AL, Sobreiro LG, et al. Soroprevalência de anticorpos anti-Toxoplasma gondii em trabalhadores de um matadouro de suínos e em indivíduos com outras atividades na cidade de Palmas, Paraná, Brasil. Cienc Rural 2007; 37(1): 292-295. https://doi.org/10.1590/S0103-84782007000100050. 
Opsteegh M, Kortbeek TM, Havelaar AH, van der Giessen JWB. Intervention strategies to reduce human Toxoplasma gondii disease burden. Clin Infect Dis 2015; 60(1): 101-107. http://dx.doi.org/10.1093/cid/ciu721.

Pena HF, Gennari SM, Dubey JP, Su C. Population structure and mouse-virulence of Toxoplasma gondii in Brazil. Int J Parasitol 2008; 38(5): 561-569. http://dx.doi.org/10.1016/j.ijpara.2007.09.004. PMid:17963770.

Silva AV, Cunha ELP, Meireles LR, Gottschalk S, Mota RA, Langoni H. Toxoplasmose em ovinos e caprinos: estudo soroepidemiológico em duas regiões do Estado de Pernambuco, Brasil. Cienc Rural 2003; 33(1): 115-119. http://dx.doi.org/10.1590/S010384782003000100018 .

Spagnol FH, Paranhos EB, Oliveira LL, de Medeiros SM, Lopes CW, Albuquerque GR. Prevalência de anticorpos anti-Toxoplasma gondii em bovinos abatidos em matadouros do estado da Bahia, Brasil. Rev Bras Parasitol Vet 2009; 18(2): 42-45. http://dx.doi. org/10.4322/rbpv.01802009. PMid:19602316.

Su C, Zhang X, Dubey JP. Genotyping of Toxoplasma gondii by multilocus PCR-RFLP markers: a high resolution and simple method for identification of parasites. Int J Parasito/ 2006; 36(7): 841-848. http://dx.doi.org/10.1016/j.ijpara.2006.03.003. PMid:16643922.

Tenter AM, Heckeroth AR, Weiss LM. Toxoplasma gondii: from animals to humans. Int J Parasitol 2000; 30(12-13): 1217-1258. http://dx.doi.org/10.1016/S0020-7519(00)00124-7. PMid:11113252.

Tenter AM. Toxoplasma gondii in animals used for human consumption. Mem Inst Oswaldo Cruz 2009; 104(2): 364-369. http:// dx.doi.org/10.1590/S0074-02762009000200033. PMid:19430665.

Triola MF. Introdução à estatística. 9th ed. Rio de Janeiro: LTC; 2005.

Vieira Da Silva A, De Oliveira Mendonça A, Bergamaschi Pezerico S, Domingues PF, Langoni H. Genotyping of Toxoplasma gondii strains detected in pork sausage. Parasitol Latinoam 2005; 60(1-2): 65-68. http://dx.doi.org/10.4067/S0717-77122005000100011. 